\title{
Kualifikasi Pemasok Bahan Baku yang Digunakan pada Industri Farmasi
}

\author{
Mika Febryati Kadir ${ }^{*}$, Iyan Sopyan²
}

${ }^{1}$ Program Studi Profesi Apoteker, Fakultas Farmasi, Universitas Padjadjaran, Jatinangor 45363

2Departemen Farmasetika dan Teknologi Farmasi, Fakultas Farmasi, Universitas Padjadjaran, Jatinangor 45363

*E-mail: mika14001@unpad.mail.ac.id

(Submit 12/2/2020, Revisi 14/2/2020, Diterima 15/2/2020)

\begin{abstract}
Abstrak
Pengadaan adalah salah satu kegiatan pendukung yang penting dalam kesuksesan sebuah perusahaan. Proses pengadaan dimulai dengan proses pemilihan pemasok yang tepat. Sertifikasi pemasok merupakan salah satu persyaratan GMP untuk dapat menghasilkan produk jadi yang memiliki mutu tinggi dan aman dan menghindari penarikan produk, kematian, kejadian efek samping yang merugikan, dan penyakit serius karena mutu rendah dari produk jadi yang dihasilkan. Dari segi bisnis untuk mencapai keuntungan, terkadang tekanan akan meningkat untuk mendapat bahan baku dengan harga rendah, yang dapat mengarah ke pengadaan bahan baku di bawah standar. Hal tersebut dapat dihindari dengan menggunakan kualifikasi pemasok sebagai alat. Artikel ini menjelaskan prosedur kualifikasi terhadap pemasok bahan baku yang akan digunakan oleh perusahaan farmasi serta menyediakan dokumen penunjangnya.
\end{abstract}

Kata Kunci : Bahan Baku, Kualifikasi, Pemasok.

\section{Outline}

- Pendahuluan

- Metode

- Hasil dan Pembahasan

- Perspektif Penulis

- Kesimpulan

- Daftar Pustaka

\section{Pendahuluan}

Pengadaan (procurement) adalah salah satu kegiatan pendukung yang penting dalam kesuksesan sebuah perusahaan. Kegiatan pengadaan tidak hanya berhubungan dengan pihak di dalam perusahaan tetapi juga pihak luar perusahaan seperti pemasok. Definisi pemasok menurut Therapeutic Goods Administration ${ }^{1}$ berupa pihak yang mendapatkan persetujuan untuk menyediakan material baik bahan baku ataupun bahan kemas untuk produk medisinal. Pemasok dapat berupa agen atau produsen bahan baku maupun bahan kemas yang sebenarnya. 
Proses pengadaan dimulai dengan proses seleksi pemasok yang tepat untuk memastikan barang yang dibutuhkan dalam proses produksi tersedia sesuai kebutuhan. Menurut Ghoddsypour dan O'Brien ${ }^{2}$ seleksi pemasok merupakan masalah pengambilan keputusan penting untuk mendapatkan pemasok yang dapat meningkatkan daya saing perusahaan. Banyak faktor mempengaruhi kemampuan perusahaan untuk memilih pemasok yang tepat. Beberapa faktor perusahaan mempertimbangkan kepercayaan dan komitmen, finansial yang memadai, mutu, waktu pengiriman yang dapat diandalkan, dan kapabilitas teknologi yang memadai3. Namun kriteria lain seperti sertifikat ISO, relabilitas, kredibilitas, referensi dan pengembangan produk juga diperlukan ${ }^{4}$.

Sertifikasi pemasok merupakan persyaratan GMP (Good Manufacturing Practices) I CPOB (Cara Pembuatan Obat yang Baik) untuk dapat menghasilkan produk jadi yang memiliki mutu tinggi dan aman, dan menghindari penarikan produk, kematian, kejadian efek samping yang merugikan, dan penyakit yang serius karena mutu rendah dari produk jadi yang dihasilkan. Fungsi industri farmasi sebagai unit bisnis memiliki tujuan utama untuk mendapatkan keuntungan. Agar mencapai hal ini, terkadang tekanan akan meningkat untuk mendapat bahan baku dengan harga rendah, yang dapat mengarah ke pengadaan bahan baku di bawah standar. Hal ini dapat dihindari dengan menggunakan kualifikasi pemasok sebagai alat.

Kinerja dari pemasok dapat mengalami perubahan baik perubahan mayor maupun minor. Maka dari itu, industri farmasi melakukan evaluasi berkala terhadap pemasok yang terdapat pada daftar pemasok yang telah disetujui oleh perusahaan. Pemasok tersebut dapat mengalami re-assessment atau bahkan diskualifikasi oleh divisi quality assurance jika terdapat defisiensi terhadap mutu yang signifikan yang dapat menyebabkan resiko serius terhadap kesehatan.

Artikel ini menjelaskan prosedur kualifikasi terhadap pemasok bahan baku yang akan digunakan oleh perusahaan farmasi serta menyediakan dokumen penunjangnya. Pedoman The International Council for Harmonization's (ICH) Q75 mendefinisikan bahan baku sebagai "bahan awal, reagen, dan pelarut yang dimaksudkan untuk digunakan dalam produksi zat antara atau API (active pharmaceutical ingredients)". Namun definisi ini dapat diperluas mencakup bahan-bahan lain yang ditambahkan ke proses pembuatan, atau yang mungkin bersentuhan dengan bahan aktif, termasuk bahan proses seperti buffer dan media serta eksipien. Bahan baku yang dibahas pada artikel ini meliputi bahan baku kritikal, bahan baku non kritikal, dan produk antara / API. Masing-masing jenis bahan harus memenuhi kualifikasi sebelum pembuatan dapat dimulai dengan aman.

\section{Metode}

Pencarian data dalam studi pustaka ini diambil berdasarkan pustaka primer berupa referensi artikel ilmiah yang berkaitan dengan kualifikasi pemasok bahan baku sediaan farmasi. Adapun kriteria yang digunakan yaitu artikel ilmiah yang dimaksudkan berupa panduan/pedoman dan naskah publikasi internasional tahun 2000-2019 dengan tema berfokus kepada prosedur ataupun tahapan melakukan kualifikasi pemasok khususnya bahan baku yang digunakan pada perusahaan industri farmasi. 


\section{Hasil dan Pembahasan}

Proses kualifikasi didefinisikan oleh American Society for Quality Control (ASQC) sebagai "proses menunjukkan apakah suatu entitas mampu memenuhi persyaratan yang ditentukan." Kualifikasi vendor adalah proses di mana vendor dievaluasi untuk menentukan apakah dapat menyediakan barang atau jasa yang diperlukan dengan standar yang diminta oleh perusahaan pembelian ${ }^{6}$. Tahapan kualifikasi pemasok di industri farmasi dapat dilihat di gambar $1^{7}$.

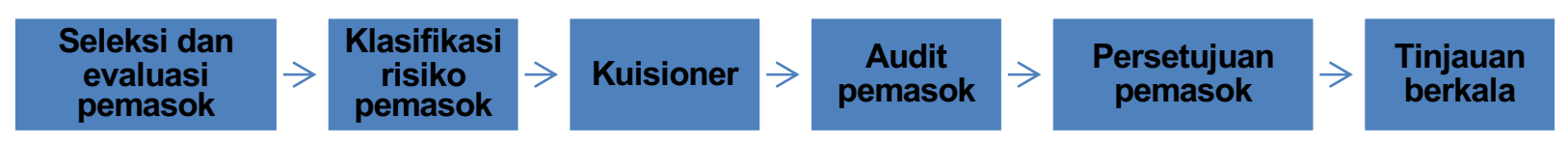

Gambar 1. Tahapan Kualifikasi Pemasok

\section{Seleksi dan Evaluasi Pemasok}

Menurut $\mathrm{Birch}^{8}$, sebelum memulai mendefinisikan kriteria yang paling penting untuk mengkaji pemasok, departemen pengadaan harus terlebih dahulu mendefinisikan pendekatan yang melibatkan hubungan antara pelanggan dan pemasok. Oleh karena itu, manajer pengadaan harus terlebih dahulu membuat perjanjian tertentu dengan pemasok dan menentukan persyaratan untuk negosiasi. Menurut penulis yang sama, kriteria untuk pemilihan pemasok dapat diklasifikasikan ke dalam lima kategori berbeda: biaya, logistik, kualitas, pengembangan dan manajemen. Sementara itu, Stevic9 melakukan literature review terhadap berbagai publikasi mengenai kriteria yang digunakan dalam seleksi dan evaluasi pemasok. Hasil review dapat dilihat di (tabel 1). Parameter keuangan, kualitas, dan pengiriman hampir semuanya merupakan studi sebagai kriteria pemilihan pemasok. Menurut penelitian yang dilakukan selain kriteria di atas dalam sejumlah besar publikasi dan kriteria berikut memainkan peran penting ialah sistem komunikasi, keandalan, fleksibilitas, kapasitas logistik, reputasi, kecepatan respon terhadap persyaratan.

Tabel 1. Kriteria pada saat seleksi pemasok

\begin{tabular}{|l|l|}
\hline Harga bahan & Kriteria Pemasok \\
\hline Stabilitas finansial & Mutu bahan \\
\hline Metode pembayaran & Waktu jaminan \\
\hline Biaya transportasi & Sertifikasi produk \\
\hline Volume diskon & Reputasi \\
\hline Waktu pengantaran & Penghargaan \\
\hline Keandalan & Sistem komunikasi \\
\hline Fleksibilitas & Kecepatan respon terhadap persyaratan \\
\hline Kapasitas logistik & Reaksi terhadap pembaruan \\
\hline Persentase realisasi ketepatan pengantaran & Teknologi informasi \\
\hline
\end{tabular}

\section{Klasifikasi Risiko Pemasok}

Setelah calon pemasok baru telah dipilih, pemasok harus diklasifikasikan berdasarkan risiko, berdasarkan jenis pertimbangan yang dijelaskan dalam tahap seleksi dan evaluasi pemasok. Demikian pula, pemasok yang sudah ada yang belum secara resmi disetujui juga harus diklasifikasikan. 
Klasifikasi pemasok dapat berubah seiring waktu jika terdapat OOS (out of spesification) ataupun NC (non conformity). Tabel 2 memperlihatkan contoh klasifikasi resiko pemasok berdasarkan Drug Office of Department Health ${ }^{10}$.

Tabel 2. Klasifikasi resiko pemasok

\begin{tabular}{|c|ll}
\hline Klasifikasi Pemasok & Produsen bahan yang digunakan dalam sediaan steril atau dengan masalah \\
\hline $\begin{array}{c}\text { Kategori 1 } \\
\text { (Highest Risk) }\end{array}$ & $\circ$ & $\begin{array}{l}\text { Contoh Pemasok } \\
\text { stabilitas yang diketahui. } \\
\text { Produsen API di negara dengan regulasi GMP yang buruk atau tidak diketahui. } \\
\text { Broker, distributor atau agen di mana rantai pasokan dari produsen kompleks, } \\
\text { tidak sepenuhnya diketahui, atau ada peningkatan kemungkinan palsu. }\end{array}$ \\
\hline $\begin{array}{c}\text { Kategori 2 } \\
\text { (Moderate Risk) }\end{array}$ & $\circ$ & $\begin{array}{l}\text { Produsen bahan yang digunakan dalam sediaan farmasi non-steril. } \\
\text { Broker, distributor atau agen yang menangani API yang memerlukan manajemen } \\
\text { rantai dingin. }\end{array}$ \\
\hline Kategori 3 & Produsen eksipien yang diproduksi di dedicated site (misal :gula) \\
\hline
\end{tabular}

Kuesioner

Kuesioner merupakan cara untuk menentukan apakah pemasok mampu memenuhi persyaratan mutu GMP untuk memasok bahan baku. Kuesioner dapat digunakan sebagai cara untuk mendapatkan informasi tentang standar mutu di lokasi pemasok. Namun, hal tersebut tidak memberikan tingkat jaminan yang sama dengan on-site audit, tetapi memiliki peran dalam hal strategi berbasis risiko ${ }^{10}$.

Kuesioner harus berisi pertanyaan yang dapat diaplikasikan pada suatu pemasok. Informasi yang memadai harus tersedia untuk menentukan bahwa pemasok memiliki sistem manajemen mutu yang tepat dan ada jaminan yang memuaskan bahwa bahan yang dipasok akan memiliki mutu yang sesuai. Kuisioner yang lengkap dan beberapa dokumentasi penunjang yang tersedia harus ditinjau secara kritis untuk menentukan penerimaan pemasok ${ }^{10}$.

Selain kuisioner, perusahaan farmasi juga harus melakukan quality assessment terhadap pemasok yang berpotensi. Melalui quality assessment, pemasok harus memastikan bahwa bahan yang dipasok berkualitas dan dapat digunakan pada setiap tahap pembuatan, dan harus memastikan bahwa bahan yang diproduksi sesuai dengan "Note for guidance on minimizing the risk of transmitting animal spongiform encelopathy agents via medicinal product"11. Bahan yang diantarkan dalam wadah tank juga harus terjamin kualitasnya. Tank harus spesifik untuk produk tertentu, dan jika tidak, pembersihan harus dijamin dengan validasi pembersihan. Ringkasan prosedur quality assessment terdapat dalam (tabel 3).

\section{cGMP Compliance History}

Kepatuhan terhadap regulasi cGMP memastikan identitas, kekuatan, kualitas, dan kemurnian produk obat dengan mengharuskan pemasok bahan baku mengendalikan operasi manufaktur secara memadai. Hal ini termasuk membangun sistem manajemen mutu yang kuat, mendapatkan bahan baku berkualitas yang tepat, membangun prosedur operasi yang kuat, mendeteksi dan menyelidiki penyimpangan kualitas produk, dan memelihara laboratorium pengujian yang andal $\left.\right|^{12}$. 
Tabel 3. Ringkasan Prosedur Quality Assessment

\begin{tabular}{|l|c|c|c|}
\multicolumn{1}{c|}{ Persyaratan } & $\begin{array}{c}\text { Bahan } \\
\text { Baku Non } \\
\text { Kritikal }\end{array}$ & $\begin{array}{c}\text { Bahan Baku } \\
\text { Kritikal }\end{array}$ & $\begin{array}{c}\text { Produk antara } \\
\text { terregistrasi / API }\end{array}$ \\
\hline TSE/BSE Assessment & $\sqrt{ }$ & $\sqrt{ }$ & $\sqrt{ }$ \\
\hline Tanker Cleaning Assessment & $\sqrt{ }$ & $\sqrt{ }$ & $\sqrt{ }$ \\
\hline Supplier/Manufactures & $\sqrt{ }$ & $\sqrt{ }$ & $\sqrt{ }$ \\
Questionnaire & & $* * \sqrt{ }$ & $\sqrt{ }$ \\
\hline Manufacturer Audit & $* * \sqrt{ }$ & $\sqrt{ }$ & $\sqrt{ }$ \\
\hline Historical Performance* & & $* * \sqrt{ }$ & $\sqrt{ }$ \\
\hline cGMP Compliance History & $* * \sqrt{ }$ & $* * \sqrt{ }$ & $\sqrt{ }$ \\
\hline 3rd Party Certification & $\sqrt{ }$ & $\sqrt{ }$ & $\sqrt{ }$ \\
\hline Contract Agreement & & $* * \sqrt{ }$ & $\sqrt{ }$ \\
\hline Quality Agreement & &
\end{tabular}

Keterangan : ${ }^{*}$ - Jika tersedia $\sqrt{ }$ - Dibutuhkan ${ }^{* *} \sqrt{ }$ - Bergantung pada pengkajian resiko yang dilakukan pada bahan yang dibeli

\section{3rd Party Certification}

Sertifikasi pihak ketiga melibatkan penilaian independen yang menyatakan bahwa persyaratan spesifik yang berkaitan dengan produk, proses, atau sistem manajemen telah dipenuhi dan juga bahwa lembaga sertifikasi memiliki pengawasan independen untuk memastikan ketidakberpihakan dan kebebasan dari konflik kepentingan. Tujuan dari program sertifikasi ini adalah untuk menerapkan pendekatan yang konsisten dalam memeriksa dan mengaudit pemasok bahan baku agar sesuai dengan cGMP bahan baku yang tepat. Selain itu, program sertifikasi pihak ketiga mencakup penggunaan lembaga sertifikasi (LS) yang kredibel yang mempekerjakan auditor berkualifikasi yang telah terbukti kompeten dalam standar terkait, untuk mengeluarkan laporan audit dan sertifikat ${ }^{13}$.

\section{Contract Agreement}

Syarat dan ketentuan kontrak, di sisi lain, dapat dinegosiasikan antara tim pembelian (purchase) dan pemasok. Dalam negosiasi, tim pembelian mencoba untuk menginduksi persyaratan yang menguntungkan dari pemasok, dan juga pemasok mencoba untuk menginduksi persyaratan yang menguntungkan dari tim pembelian. Tim pembelian dan pemasok berpotensi mendapat manfaat jika negosiasi antarpihak adalah situasi yang saling menguntungkan. Peran dan tanggung jawab tim pembeli untuk negosiasi juga harus dipahami, didefinisikan, dan dikomunikasikan dengan jelas. Setiap perbedaan dan kesenjangan dari dokumen pengajuan perlu diatasi, diperhatikan hal-hal tertentu seperti kelengkapan kombinasi harga dari dokumen uji penerimaan, estimasi waktu proyek, perjanjian pemeliharaan, dan ketentuan pembayaran ${ }^{14}$.

\section{Quality Agreement}

Quality agreement adalah dokumen yang mendefinisikan parameter mutu spesifik dan pihak mana yang bertanggung jawab atas pelaksanaan parameter tersebut. 
Supplier quality agreement menetapkan ekspektasi industri farmasi terkait kinerja pemasok untuk memastikan bahwa produk dan / atau layanan pemasok memenuhi kualitas dengan memastikan kepatuhan terhadap cGMP yang berlaku untuk semua produksi, pengujian, atau operasi dukungan lainnya ${ }^{5,15}$.

\section{Audit Pemasok}

Unit Quality bertanggung jawab untuk mengevaluasi kualitas pemasok. Jika perlu, tim audit harus dibentuk dengan personel yang memiliki kualifikasi yang tepat untuk mengaudit pemasok. Kuesioner audit harus disesuaikan dengan bahan baku yang akan dibeli, metode pembuatannya, API, cairan steril, dan proses bioteknologi ${ }^{10}$.

- Audit harus bertujuan untuk menemukan apakah pabrik yang diaudit memiliki potensi untuk memasok ke standar peraturan yang berbeda, jika diperlukan di masa depan?

- Apakah pemasok ini memiliki potensi untuk menjadi mitra jangka panjang?

Auditor juga harus memutuskan sejauh mana audit harus dilakukan. Jika perlu, audit ulang harus dilakukan dengan perbaikan yang tepat. Temuan audit harus membahas kapabilitas pemasok, dan harus membantu dalam mengambil keputusan ya - tidaknya dalam tahap persetujuan pemasok ${ }^{10}$.

\section{Persetujuan Pemasok}

Kuisioner yang lengkap (dengan bukti lain yang diminta) dapat digunakan untuk menyetujui pemasok Kategori 3 (risiko terendah). Jika digunakan untuk menyetujui pemasok Kategori 2 (risiko sedang), justifikasi harus didasarkan pada risiko dan didokumentasikan. Untuk pemasok Kategori 1 dan Kategori 2 yang membutuhkan audit, laporan audit dan respons pemasok terhadap laporan tersebut harus dievaluasi. Semua tindakan korektif yang timbul dari on-site audit harus pada tahap closed atau completion agar pemasok disetujui. Jika bukti audit oleh pihak ketiga telah diterima (Sertifikat GMP, salinan laporan audit, respons, dan closing), bukti dokumentasi tersebut harus dievaluasi. Berdasarkan hasil evaluasi, pemasok dapat disetujui atau tidak disetujui. Dalam beberapa keadaan mungkin layak untuk menetapkan status persetujuan bersyarat (10 bets pertama dari pemasok baru yang akan diuji sepenuhnya).

\section{Tinjauan Berkala}

Secara berkala, biasanya sekali dalam setahun, kinerja pemasok harus dinilai. Bergantung pada jenis bahan, data berikut harus dievaluasi ${ }^{16}$ :

- Pengujian penuh material secara berkala

- Kualitas - misalnya jumlah pengiriman yang tidak sesuai (non conformity)

- Situasi keluhan

- Tinjauan kualitas produk (zat perantara dan API)

- Penilaian perubahan (bahan kritikal, zat perantara dan API)

- Reaksi terhadap rencana audit dan remediasi (jika audit telah dilakukan)

- Waktu respons untuk keluhan dan pertanyaan 
- Waktu reaksi jika, misalnya persyaratan regulasi berubah (bahan kritikal, zat perantara, dan API)

- Masalah kepatuhan regulasi atau cGMP (bahan kritikal, zat perantara, dan API)

Tinjauan pemasok bertujuan untuk memeriksa secara terus-menerus kinerja mutu barang yang dipasok dan pemasok masing-masing secara keseluruhan, menghasilkan Key Performance Indicator (KPI) dan skor, serta informasi penting untuk memperbaiki hasil yang tidak diinginkan, untuk mengidentifikasi/mencegah potensi kegagalan dan untuk menyediakan bukti untuk mendukung keputusan yang terkait dengan basis pemasok $^{17}$.

Selain tahapan di atas, ada pendekan lain yang dapat digunakan kualifikasi pemasok. Pendekatan QUEST adalah salah satu pendekatan yang sering digunakan dalam kualifikasi pemasok. QUEST terdiri dari 5 tahap yakni Question, Understand, Evaluate, Site Audit, dan Track ${ }^{18}$.

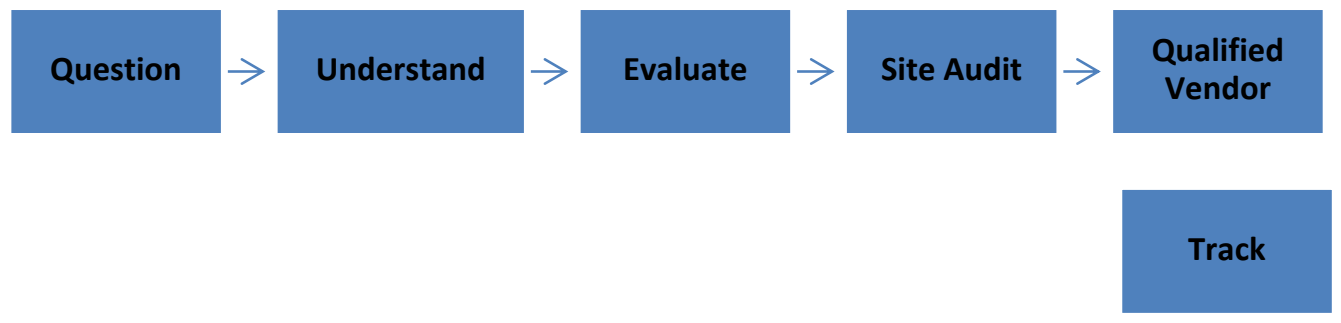

Gambar 2. Pendekatan QUEST

$Q=$ Fase Question :

Jenis bahan baku apa yang diperlukan untuk pembuatan produk obat untuk memenuhi karakteristik, keamanan, dan efikasi sediaan farmasi. Spesifikasi yang ditetapkan untuk bahan baku yang dibutuhkan harus disiapkan dengan alasan ilmiah di balik penggunaan yang diusulkan ${ }^{6,19}$.

$\mathrm{U}=$ Fase Understand :

Persyaratan spesifik terkait dengan material yang dikualifikasi seperti ukuran partikel dan fungsi khusus. Berdasarkan uji coba awal yang dilakukan pada skala laboratorium dan hasil kompatibilitas, stabilitas dan aktivitas pengembangan, persyaratan bahan baku dapat diselesaikan. Alasan ilmiah harus tersedia dalam bentuk uji coba laboratorium atau melalui literatur yang diterbitkan ${ }^{6,19}$.

$E=$ Tahap Evaluate :

Identifikasi pemasok yang berpotensi terbaik. Berdasarkan persyaratan, vendor yang memiliki potensi dapat diidentifikasi ${ }^{6,19}$. 
$S=$ Fase audit lokasi :

Verifikasi secara on-site dan off-site. Berdasarkan kritikalitas dari bahan baku, audit secara on-site harus dilakukan ${ }^{6,19}$.

$\mathrm{T}=$ Fase Track :

Monitor dan rekualifikasi ulang. Kinerja pemasok harus dimonitor secara terus menerus. Proses monitor melibatkan peninjauan masalah yang terkait dengan barang atau layanan yang disediakan oleh pemasok. Jadwal ditentukan sehingga setiap pemasok yang terkualifikasi akan dikualifikasi ulang secara berkala ${ }^{6,19}$.

\section{Perspektif Penulis}

Pemikiran penulis dalam review artikel ini didasarkan prosedur melakukan kualifikasi pemasok yang dilakukan departemen quality assurance setelah melewati tahapan pemilihan pemasok. Secara umum, proses kualifikasi pemasok cenderung sama, namun yang perlu diperhatikan ialah dokumen-dokumen penunjang yang disesuaikan dengan budaya industri farmasi sebagai pemesan, misalnya sertifikasi halal. Untuk itu, perlu untuk terus mengumpulkan dan memproses informasi tentang pemasok, dengan membangun dan memelihara koneksi yang memadai dengan mereka, maka perlu untuk mengembangkan dan menerapkan metode yang sesuai dalam melakukan kualifikasi terhadap pemasok potensial.

\section{Kesimpulan}

Tujuan utama dari setiap industri farmasi adalah untuk menghasilkan produk obat yang aman, memiliki identitas, potensi, dan kemurnian serta berkualitas baik. Untuk menjaga kualitas, bahan baku harus dibeli dari pemasok yang kompeten, diidentifikasi dan dievaluasi untuk kompetensinya. Kualifikasi pemasok yang tepat akan memastikan kualitas bahan baku yang masuk dan mengurangi biaya yang terlibat dalam pengujian ulang. Kualifikasi pemasok akan meningkatkan kepercayaan suatu perusahaan untuk menghasilkan produk yang berkualitas baik.

\section{Daftar Pustaka}

1. Therapeutic Goods Administration. Supplier Qualification : Technical Working Groups (TWG) on Non-Sterile Medicines \& Complementary Medicines. Technical Guidance on the Interpretation of Manufacturing Standards. 2010;Issue 1:5.

2. Ghoddsypour SH, O'Brien C. The Total Cost of Logistic in Supplier Selection, under Conditions of Multiple Sourching, Multiple Criteria and Capacity Constrains. Int J of Prod Econ. 2001;73:15-27.

3. Cox A. Power, Value and SCM. Supply Chain Management: An Int J. 1999;4(4):16775.

4. Harps LH. The Haves and the Have Nots. Supply Chain Practices for the New Millenium: Inbound Logs J. 2000:75-114. 
5. ICH. Q7 GMP Practice Guidance for Active Pharmaceutical Ingredients. United States : U.S. Department of Health and Human Services; 2016.

6. Cafmeyer N, Lewis, JM. How to Develop a Practical (and Compliant) Vendor Qualification Program. [diunduh 10 Februari 2020]. Tersedia dari : http://pharmtech.findpharma.com/pharmtech/Article/How-to-Develop-a-Practicaland-Compliant-VendorQu/ArticleStandard/Article/detail/632990

7. APIC. Supplier Qualification \& Management Guideline. Brussel : European Chemical Industry Council; 2009.

8. Birch D. Made for Each Other. Supply Management. 2001:42-43.

9. Stevic Z. Criteria for Supplier Selection : A Literature Review. In J of Eng, Bus, and Enp App. 2017;19(1):26-27.

10. Drug Office Department of Health. Guidance for Industry: Material Supplier Management. Ver 2.0. 2019. [diunduh 11 Februari 2020]. Tersedia dari : https://www.drugoffice.gov.hk/eps/do/en/doc/guidelines forms/Draft Guidance for I ndustry Material Supplier Management.pdf

11. EMA. Note for Guidance in Minimizing The Risk of Transmitting Animal Spongiform Encephalopathy Agents via Medicinal Product, EMEA/410/01. Off J of the Eur Uni. 2011;C73:1-17.

12. FDA. Facts About the Current Good Manufacturing Practices (CGMPs). 2018. [diakses 13 Februari 2020]. Tersedia dari https://www.fda.gov/drugs/pharmaceutical-quality-resources/facts-about-currentgood-manufacturing-practices-cgmps

13. Klugh DB, Lindblad RD, Muse DG, Ulman KL, Walsh P, Zawislak PS. Third-Party Audits : Ensuring That Excipients Meet cGMP Requirements. Pharmaceutical Technology. 2018;4:10-13.

14. Jayshingpure AG, Khona AC, Narkhede BE, Nagare MR. A Conceptusl Framework for Vendor Selection. IOSR J of Bus \& Manag. 2016;18(6): 130-131.

15. FDA. Contract Manufacturing Arrangements for Drugs: Quality Agreements Guidance for Industry. United States : Department of Health and Human Services Food and Drug Administration; 2016.

16. Shadie PJ. Qualification of Raw Materials for Biopharmaceutical Use. 2004. BioPharm International. 2014;17(2). [diakses 11 Februari 2020]. Tersedia dari : https://www.biopharminternational.com/qualification-raw-materialsbiopharmaceutical-use?id=\&sk=\&date $=$ \&pagelD $=3$

17. Malega P, Supplier Quality Assurance - Step to Competitive Advantage. Int Sci J about Log. 2016;3(2):17.

18. Patel KT, Chotai NP. Vendor Qualification for Pharmaceutical Excipients - GMP Requirement and Approach. Pharmazie. 2010;65: 785.

19. Pharmaceutical Technology Editors. How to Develop a Practical (and Compliant) Vendor Qualification Program. Pharmaceutical Technology. 2009;33(10). [diakses 11 Februari 2020]. Tersedia dari : http://www.pharmtech.com/how-develop-practicaland-compliant-vendor-qualification-program-0?id=\&sk=\&date=\&pagelD=2 